\title{
TINJAUAN KRITIS ATAS KEBIJAKAN PEMBERIAN POTONGAN PELUNASAN ANGSURAN MURABAHAH BERDASARKAN NILAI KEDERMAWANAN ISLAM TJOKROAMINOTO
}

\author{
Yudhy Muhtar Latuconsina
}

\author{
Universitas Darussalam Ambon \\ JL. Raya Tulehu, Km 24, Salahutu, Kabupaten Maluku Tengah, Maluku \\ Email:yudhymuhtar@yahoo.co.id
}

Abstract

The purpose of this research is to criticize the policy in discounting of Murabahah's installment payment in Islamic banking based on Islamic benevolent value of Tjokroaminoto. The critical method of Islamic Tjokroaminoto was used to criticize the policy in discounting of Murabahah's installment payment in Islamic banking. The result shows that the profit's domination and egoistic attitude had influenced the policy of margin's discount in Murabahah's installment payment when the clients hastened their installment payment period. The major opportunity in giving this kind of discounting is the financial ability of middle up customers and this may imbalance wealth. The solution which built based on Islamic benevolent value of Tjokroaminoto is used to evaluate the subject and the object that deserve to get aid. The aid is for the customer who had inability in paying the installment and the margin discounts were should be influenced by the condition of customer and Islamic banking interest.

Keywords: the policy of installment payment's discount, Murabahah, Islamic benevolent value of Tjokroaminoto 
Abstrak

Tujuan dari penelitian ini adalah kritik atas kebijakan pemberian potongan pelunasan angsuran murabahah di perbankan syariah berdasarkan nilai kedermawanan Islam Tjokroaminoto. Metode kritis Islam Tjokroaminoto digunakan untuk mengkritisi kebijakan pemberian potongan pelunasan angsuran murabahah di perbankan syariah. Hasil penelitian menunjukkan adanya dominasi keuntungan yang menunjukkan sikap egoistik yang mempengaruhi kebijakan pemberian potongan margin sehingga yang diberikan hanya atas pelunasan pembayaran angsuran murabahah lebih cepat dari waktu jatuh temponya. Peluang terbesar diberikannya potongan ini adalah nasabah kelas atas karena kemampuan finansial-nya sehingga dimungkinkan adanya ketimpangan kesejahteraan. Solusi yang dibangun berdasarkan nilai kedermawanan Islam Tjokroaminoto adalah evaluasi subjek dan objek penerima dengan mengutamakan kepada nasabah yang membutuhkan pertolongan yaitu mengalami penurunan kemampuan membayar angsuran serta besaran potongan margin yang dipengaruhi oleh kondisi nasabah dan kepentingan perbankan syariah.

Kata kunci: kebijakan potongan pelunasan, murabahah, nilai kedemawanan islam tjokroaminoto

\section{PENDAHULUAN}

Pemberlakuan potongan angsuran murabahah diatur dalam Pernyataan Standar Akuntansi Keuangan (PSAK) 102 paragraf 26, 27 dan 28. PSAK 102 merupakan pedoman akuntansi untuk transaksi pembiayaan murabahah yang menjadi rujukan bagi seluruh perbankan syariah. Dalam paragraf 26 disebutkan bahwa potongan pelunasan piutang murabahah yang diberikan kepada pembeli yang melunasi tepat waktu atau lebih cepat dari waktu yang disepakati. Menurut Wiroso (2010:113), potongan pembayaran angsuran murabahah dalam PSAK 102 paragraf 26 diberikan atas dasar prestasi yang dilakukan nasabah yang ditujukan oleh ketepatan waktu pembayaran, pembayaran angsuran lebih cepat atau lebih dahulu dari yang ditetapkan. Bagi perbankan syariah, ini merupakan bentuk prestasi karena terpenuhi janji dan tanggungjawabnya untuk melakukan pembayaran angsuran murabahah sesuai dengan kesepakatan awal.

Paragraf 27 dalam PSAK 102 berkaitan dengan metode akuntansi yang digunakan dalam pemberian potongan kepada nasabah (baca: nasabah) yang berkaitan dengan cara perlakuannya. Terdapat dua perlakuan akuntansi, yang pertama diberikan saat pelunasan dengan mengurangi piutang murabahah dan diberikan setelah pelunasan dengan menerima pelunasan kemudian memberikan potongan kepada pembeli. pengakuan, pengungkapan serta penyajian dalam laporan keuangan. Sedangkan sustansi paragraf 28 menerangkan tentang pengakuan akuntansi 
potongan pelunasan angsuran murabahah. Paragraf 28 juga menjelaskan tentang subjek penerima potongan angsuran murabahah yaitu bagi nasabah pembiayaan yang mengalami penurunan kemampuan pembayaran. Dengan demikian terdapat tiga subjek penerima potongan pembayaran angsuran murabahah yaitu nasabah yang melakukan pelunasan tepat waktu, lebih cepat dari jangka waktu jatuh tempo dan yang mengalami penurunan kemampuan pembayaran.

Pemberian potongan angsuran pembayaran murabahah yang diatur dalam PSAK 102 paragraf 26 dan 27 dikuatkan dengan Fatwa DSN-MUI Nomor 23/ DSN-MUI/III/2002 yang diprioritaskan kepada pelunasan tepat waktu dan lebih awal waktu. Sedangkan untuk paragraf 28 dikuatkan Fatwa DSN-MUI Nomor 46/DSN-MUI/II/2005 tentang potongan tagihan murabahah. Kedua fatwa merupakan bentuk legalitas syariah terhadap perlakuan pemberian potongan pelunasan. Menurut Wiroso (2011:126), kedua fatwa ini dikeluarkan disebabkan karena pengakuan adanya itikat baik dari nasabah untuk memenuhi kewajibannya sehingga penghargaan layak diberikan kepadanya. Namun dalam kedua fatwa ini, hal penting yang perlu diperhatikan adalah pemberian potongan pelunasan angsuran murabahah tidak boleh diperjanjikan dalam akad sebagai bentuk kesepakatan antar nasabah dan perbankan syariah. Kedua fatwa ini juga menegaskan bahwa besaran potongan yang akan diberikan kepada nasabah tergantung dari kebijakan perbankan syariah.

Persyaratan "tergantung kebijakan" perbankan syariah untuk memberikan potongan menunjukkan bahwa potongan tersebut memiliki kemungkinan diberikan atau tidak diberikan walaupun dengan berbagai kondisi yang disebutkan di atas. Artinya, walaupun telah melakukan pelunasan tepat waktu, lebih cepat dari waktunya dan mengalami penurunan kemampuan pembayaran, perbankan syariah dapat menetapkan kebijakan tidak memberikan kepada nasabah. Kondisi ini dimungkinkan terjadi karena memang potongan tersebut tidak diperjanjikan di dalam akad sehingga bagi perbankan syariah hal itu tidak wajib untuk diimplementasikan.

Realitas kebijakan pemberian potongan, jika ditelaah lebih mendalam, maka akan memberikan gambaran bahwa yang lebih mendominasi dalam pemberian potongan angsuran adalah nasabah yang membayar tepat waktu atau lebih cepat. Hal ini sangat beralasan karena pelunasan lebih cepat berkaitan dengan perputaran modal perbankan syariah. Semakin cepat perputaran modal murabahah maka semakin cepat keuntungan keuntungan diperoleh perbankan syariah. Percepatan keuntungan perbankan syariah adalah "berita bahagia" akantetapi apakah tujuan tersebut berbanding lurus dengan tujuan perbankan syariah yaitu pemerataan kesejahteraan rakyat?, ataukah hanya bertujuan memberikan keuntungan pribadi dan pihak ketiga yang menyertakan dana di perbankan syariah?. Jika benar, maka hakekatnya perbankan syariah masih berada dalam belenggu perbankan konvensional kerena kesamaan kebijakan yang ditetapkan.

Realitas ini dapat dibenarkan jika kita mencoba merajut benang merah dengan nasabah yang diberikan potongan margin karena penurunan kemampuan pembayaran 
angsuran. Kebijakan ini mungkin sangat jarang dilaksanakan karena jika terjadi penuruan pembayaran angsuran maka perbankan syariah akan memberikan saksi berupa denda sebagaimana di atur dalam PSAK 102 paragraf 29. Walaupun dengan alasan nasabah tersebut lalai akantetapi bagi nasabah yang terlambat melakukan pembayaran angsuran bulanannya tetap dikenai sanksi denda. Apabila nasabah tersebut tidak mampu lagi membayar angsuran maka akan dilakukan penjadwalan kembali dan apabila dinilai tidak mampu melunasi hutang murabahahnya maka agunan (baca: jaminan) yang telah ditetapkan diawal akad, akan dijual untuk menutupi hutang tersebut (Wiroso, 2011:137). Maka perhatikanlah prosedur ini dan kita akan dapat menyimpulkan bahwa potongan pelunasan pembayaran angsuran murabahah tidak akan diberikan kepada nasabah yang mengalami penurunan kemampuan pembayaran.

Apa latar belakangnya? Tidak lain dan tidak bukan adalah keuntungan. Kondisi ini pada hakekat nya sama dengan "jalan cerita" perbankan konvensional. Perbedaan hanya terdapat pada substansi produknya akan tetapi kebijakannya tetap sama yaitu mengarah kepada keuntungan semata. Dengan kata lain, perbankan syariah juga mengikuti jejak perbankan konvensional yaitu tidak mau menanggung kerugian. Maksimalisasi keuntungan tidak menjadi hal yang tabu, namun perlu dipahami bahwa dalam Islam keuntungaan tidak hanya berupa materi fisik saja akan tetapi terpenuhi juga aspek non-materinya. Rivai dan Usman (2012:306) menyebutnya dengan keuntungan duniawi dan ukhrawi. Triyuwono (2011) menyatakan bahwa aspek non-materi berkaitan dengan alam rasa (bahagia, rasa senang, kasih-sayang dan sebagainnya) yang mengantarkan kepada peningkatan spiritulitas keislaman. Hal ini dikarenakan dasar filosofi perbankan syariah yang dilandasi oleh fundamental values yang mana substansi nilainya jelas dan tegas (Yasin, 2010:4). Menyandang lembaga yang berlabel syariah maka diwajibkan untuk meinternalisasikan semua nilai Islam ke dalam semua kebijakan termasuk dalam pemberian potongan atas pelunasan pembiayaan murabahah.

Potongan atas pelunasan angsuran murabahah merupakan bentuk kemudahan yang diberikan kepada nasabah sebagai bentuk penerapan nilai Islam. Kemudahan tersebut merupakan upaya menolong nasabah yang membutuhkan dan ini merupakan bentuk kedermawanan perbankan syariah (Kedermawanan Islam). Namun, dengan realitas di atas, perlu adanya pengkritisan yang membangun untuk mengawal dan mengawasi kebijakan yang ditetapkan agar perbankan syariah lebih mengarah ke lembaga Islam yang kaffah. Untuk itulah penelitian ini dilakukan dengan mengkritisi kebijakan pemberian potongan atas pelunasan angsuran murabahah dengan menggunakan tolak ukur (alat analisis) nilai kedemawanan Islam dalam pemikiran kritis Islam Tjokroaminoto. Dengan demikian, tujuan penelitian ini adalah mengkritisi kebijakan pemberian potongan atas pelunasan angsuran murabahah. Penelitian ini tidak hanya sampai pada pengkritisan semata akan tetapi solusi akan tetap dibangun berdasarkan nilai kedermawanan Islam Tjokroaminoto. Hasil penelitian 
ini diharapkan memberikan kontribusi kebijakan yang bersifat praktis dan sumbangsih teoritis yang melandasi kebijakan tersebut. Penelitian ini juga diharapkan dapat memberikan masukan kepada regulator (DSN-MUI dan DSAK-IAI) agar penentuan potongan pelunasan angsuran murabahah lebih bersubstansi nilai Islam di perbankan syariah.

\section{METODE PENELITIAN}

Penelitian ini menggunakan pendekatan kualitatif dengan metode kritis Islam Tjokroaminoto. (Prastowo 2012:23) yang mengartikan penelitian kualitatif sebagai penelitian yang bermaksud untuk memahami fenomena apa yang dialami oleh subjek penelitian misalnya perilaku, persepsi, motivasi, tindakan dan lain sebagainya secara holistik dan dengan cara deskripsi dalam bentuk kata-kata dan bahasa, pada suatu konteks khusus yang alami dan dengan memanfaatkan berbagai metode alamiah. Sedangkan metode kritis yang digunakan adalah pemikiran kritis islam Tjokroaminoto yang berbeda dengan paradigma kritis pada umumnya seperti pemikiran Aristoteles, Foucault, Gadamer, Hegel, Marx, Kant, Wittgenstein dan pemikiran-pemikiran lain. penelitian ini menggunakan standar nilai Islam dalam pemikiran Tjokroaminoto sehingga metode ini lebih tepat disebut dengan paradigma kritis Islam.

Secara umum, teori kritis merupakan dasar pijakan paradigma kritis yang memandang realitas sosial sebagai realitas yang sangat kompleks, memiliki kontradiksi, konflik dan eksploitasi sehingga tidak mengherankan bila ilmu pengetahuan dipandang sebagai alat yang digunakan untuk membebaskan dan memberdayakan manusia dan juga menganggap ilmu pengetahuan itu tidak bebas dari nilai (not value free) (Sutriono dan Hanafie, 2007:36). Teori kritis secara umum bertujuan untuk mendobrak realitas untuk menghilangkan berbagai bentuk dominasi dan mendorong kebebasan, keadilan dan persamaan (Suka, 2012). Secara khusus dalam bidang akuntansi menurut Djamhuri (2011), kajian kritis digunakan untuk melakukan emansipasi atau peningkatan derajat mereka yang tertindas dan dirugikan (setidaknya tidak diuntungkan) oleh proses sosial yang menghasilkan atau melibatkan penggunaan informasi akuntansi, baik dalam ranah publik ataupun dalam ranah organisasi secara individual.

Paradigma kritis Islam ini secara umum sama dengan pola kritis sebelumnya seperti kritis terhadap dominasi tertentu, ketidakadilan dan sebagainya. Namun, kritis ala Tjokroaminoto tidak hanya berorientasi kepada fisik keduniaan akantetapi adanya campurtangan Tuhan dalam setiap aktivitasnya. Sebagaimana pernyataan Tjokroaminoto (1950:22) bahwa pemikiran kritis marxis dan lain-lain masih berorientasi kepada kebendaan (historical materialisme) yang menafikan unsur ketuhanan dalam kehidupan. Hasil akhir dari pemikiran kritis Islam ini tidak hanya sebatas menghadirkan kesadaran yang bersifat umum akantetapi mengarah kepada 
kesadaran yang berorientasi keislaman Mulawarman (2014). Pokok penting pemikiran Tjokroaminoto lebih menekankan kepada pengkritisan terhadap perilaku kapatilistik yaitu dominasi orientasi materialistis yang menghasilkan sikap egoistik dan mementingkan diri-sendiri (1950:72).

Dalam penelitian ini, langkah-langkah yang dilakukan dalam menganalisis data antara lain a) Krisis dan kritik realitas. Pada tahap ini peneliti akan mengungkap bentuk krisis dalam kebijakan pemberian potongan pelunasan angsuran murabahah dan mengkritisi cara perbankan syariah dalam mengaplikasikannya. b) Solusi atas realitas. Dalam tahap ini, nilai kedermawanan Islam Tjokroaminoto akan digunakan untuk mengatasi masalah dalam pemberian potongan angsuran murabahah yang menghasilkan bentuk penyadaran dan struktur Islami (Mulawarman:2014).

Informan dalam penelitian ini adalah aktor di perbankan syariah yang terlibat dalam seluk-beluk pembiayaan murabahah. Konsentrasi dalam pembiayaan murabahah diarahkan kepada kebijakan pemberian potongan pembayaran angsuran sehingga diharapkan para informan memiliki pengetahuan yang mendalam terkait fokus tersebut. Adapun daftar informan antara lain Bapak Helmi dari Bank Muamalat Malang, Bapak Pandu dari Bank Tabungan Negara Syariah Malang, Ibu Mashita dari Bank Mandiri Syariah Ambon dan ketiganya menjabat sebagai marketing staff.

\section{HASIL DAN PEMBAHASAN}

\section{Realitas Penerapan Pemberian Potongan Pelunasan Angsuran Murabahah di Perbankan Syariah}

Sebagaimana yang diketahui, bahwa pemberian potongan diterapkan kepada nasabah yang melakukan pelunasan tepat waktu, lebih awal dan karena penurunan kemampuan membayar angsuran. Permisalan pelunasan lebih awal dicontohkan oleh Bapak Helmi bahwa:

"Kalau mau pelunasan lebih cepat misalkan jangka waktunya 10 tahun, 2 tahun sudah berjalan kan tinggal 8 tahun, ditahun ketiga ini misalkan sisa hutang nasabah sekarang tinggal 100 juta, "mas sekarang sudah ada uang 100 juta nih, mau ditutup pembiayaan saya, boleh.

Contoh pelunasan di percepat juga disampaikan oleh Ibu Mashita bahwa: "Contoh pelunasan dipercepat, misalnya nasabah membayar untuk jangka waktu 5 tahun tapi dalam jangka waktu 3 tahun dia punya rezeki untuk melunasi.

Penjelasan informan di atas memberikan gambaran bentuk pelunasan lebih awal untuk mendapatkan potongan pembayaran angsuran murabahah. Pelunasan lebih awal tidak membatasi waktu percepatannya. Artinya, nasabah dapat 
melakukan percepatan pelunasan sesuai dengan keinginan mereka. Misalnya berdasarkan keterangan informan di atas, pelunasan dapat dilakukan di tahun ke-3 dalam jangka waktu 10 tahun pembayaran atau bahkan di awal-awal waktu angsuran sesuai dengan kemampuan nasabah.

Potongan angsuran pembayaran murabahah memberikan kemudahan kepada nasabah dalam upaya menyelesaikan kewajibannya. Semakin besar potongan yang diberikan kepada nasabah maka semakin kecil beban pembayaran angsuran murabahahnya dan ini merupakan bentuk kepedulian perbankan syariah terhadap mereka. Seperti dijelaskan sebelumnya, besar-kecilnya potongan margin tergantung kepada kebijakan masing-masing perbankan syariah. Bapak Helmi juga menyatakan pendapat sejalan bahwa:

“...kan ada sisa pokok dan ada margin, margin ini biasanya dapat potongan, entah berapa persen itu tergantung keputusan manajer, entah itu 50\% ataukah 30\% tergantung negosiasikan"

Pernyataan informan di atas menunjukan bahwa besaran potongan margin masih melalui negosiasi dengan atasan. Negosiasi yang dilakukan dengan menyampaikan keinginan nasabah untuk mendapatkan potongan margin tertentu kepada kepala cabang. Berapapun hasilnya, berpulang kepada keputusan kepala cabang, dapat berupa $50 \%$ ataupun $30 \%$. Berbeda dengan bank syariah yang dinaungi bapak Helmi, besaran potongan margin yang diberikan oleh bank syariah Ibu Mashita telah tersistem dengan baik. Artinya, terdapat rumus tertentu yang telah disiapkan untuk mendapatkan besaran potongan margin murabahah. Seperti yang dijelaskan oleh beliau bahwa:

"Kalau di bank lain, kredit 5 tahun trus dia mau menutupi 1,2,3,4 atau 5 tahun tetap bayar semuanya 5 tahun sampai lunas nanti kemudian diberikan potongan 5 atau 6 bulan untuk marginnya sedangkan kalau di BSM cuma membayar pokok dan 2 kali margin ditambah biaya administrasi”

Demikian pula yang disampaikan oleh Bapak Pandu, bahwa:

“...Pelunasannya, pokok ditambah 1 kali margin"

Keterangan informan di atas menunjukkan bahwa kebijakan besaran margin dikembalikan kepada bank syariah masing-masing. Ada yang melalui proses negosiasi dengan atasan namun ada pula yang tersistem secara langsung. Hasil kebijakan melalui negosiasi digunakan dengan pertimbangan besarnya keuntungan yang diperoleh. Hal ini seperti yang dijelaskan oleh Bapak Helmi bahwa:

El-Muhasaba, Vol. 7, No 1, Januari 2016 
"Intinya bank itu menjual jasa untuk mencari keuntungan jadi kita lihat-lihat dulu kondisi dan situasi, misalkan 50\% dirasa cukup untuk memperoleh keuntungan ya sudah"

Kondisi yang dimaksudkan dalam pernyataan di atas menunjukan bahwa negosiasi penentuan potongan margin dilakukan untuk memastikan besarnya keuntungan yang telah didapatkan dari pembiayaan murabahah. Artinya, untuk menetapkan kebijakan tersebut, perbankan syariah melakukan proses analisis agar mendapatkan kejelasan tentang berapa besar potongan margin yang tepat untuk diberikan kepada nasabah.

Potongan margin yang ditentukan tanpa negosiasi dimana porsinya telah ditentukan dari kebijakan yang bersifat tetap juga mempertimbangkan keuntungan. Ini terlihat pada Bank Syariah Mandiri (BSM) dan Bank Tabungan Negara (BTN) Syariah dengan menetapkan potongan margin dengan hanya membayar 2 atau 1 kali margin sehingga sisa margin yang lain dihapus. Ketetapan kebijakan dalam pemberian potongan margin telah dijalankan dengan strategi penerapan metode yang tepat yaitu metode anuitas. Konsep anuitas dijelaskan oleh Bapak Helmi bahwa:

"Yang bank pake itu sistem anuitas (peneliti: apakah aturan dan BI atau bank sendiri?). itu dari bank sendiri, itu seperti piramida terbalik, biasanya pokok kecil dan margin besar di awal, semakin lama margin semakin kecil sedangkan pokoknya semakin besar tapi jumlah angsuran tetap setiap bulannya, kenapa begitu? itu salah satu cara untuk metigasi resiko, nasabah sewaktu-waktu macet dari pihak bank masih mendapat keuntungan, dia sudah dapat memperoleh margin yang cukup besar tapi outstanding tetap dibayar".

Sebagimana yang terlihat dalam uraian informan ini, prinsip anuitas dapat digambarkan seperti piramida terbalik. Susunan angsuran yang dibayarkan dengan komposisi margin besar diawal dan semakin kecil diakhir sedangkan pokok angsuran berbanding terbalik yaitu kecil di awal dan semakin besar di akhir. Besaran angsuran tetap sama akan tetapi yang berbeda adalah komposisinya. Penggunaan metode anuitas memberikan kepastian keuntungan bagi perbankan syariah lebih awal. Artinya, dalam perjalanan mengangsur, keuntungan dari margin telah diperoleh sejak pertama kali pembayaran dan semakin berkurang disetiap bulannya. Jika nasabah melakukan pelunasan lebih awal diakhir periode angsuran maka pada hakekatnya potongan margin yang diberikan hanya sedikit. Hubungan ini dijelaskan oleh bapa Pandu bahwa: 
"Dulu, angsuran 2 juta, margin dan pokok ini kan 1 juta dan 1 juta tapi tetap marginnya gak berubah, sekarang bank syari'ah itu seperti ini (menggambarkan metode anuitas) sejak tahun 2008, otomatis dari sudut pandang bank jelas lebih cepat untung, seandainya dilunasi disini (awal pembayaran) nasabah untung, kalau dilunasi ditengah-tengah masih sama-sama untung, kalau dilunasi disini (akhir angsuran) nasabah sedikit dirugikan."

Penjelasan informan di atas menunjukkan perjalanan histori penentuan metode angsuran di mana sebelumnya menggunakan metode flat dengan komposisi seimbang antara pokok dan margin murabahah. Seiring perkembangan perbankan syariah maka metode ini diganti dengan metode anuitas yang memberikan keuntungan lebih awal kepada mereka. Penggunaan metode flat berpengaruh terhadap pemberian potongan angsuran murabahah karena margin yang dijadikan sebagai objek potongan masih lebih besar sehingga Berbeda dengan penggunaan yang digunakan adalah flat per bulan dimana angsuran pokok dan margin sama porsinya maka potongan yang diterima nasabah akan lebih besar lagi sehingga penggunaan metode anuitas juga bertujuan untuk memetigasi resiko dimana keuntungan perbankan syariah dapat terpenuhi.

\section{Kuatnya Orientasi Keuntungan Dalam Kebijakan Pemberian Potongan Pelunasan Angsuran murabahah}

Pemberian potongan pelunasan angsuran murabahah lebih tepatnya dinamakan dengan pemberian potongan margin karena realitas menunjukkan bahwa yang diberikan potongan hanyalah angsuran margin bukan angsuran pokok pembiayaan. Realitas ini memberikan gambaran bahwa ada pemisahan antara margin dan pokok pembiayaan dalam kebijakan pemberian potongan atas pelunasan angsuran murabahah. Jika margin menjadi objek potongan maka yang berkurang adalah keuntungan yg diperoleh dari pembiayaan murabahah.

Keterangan yang disampaikan oleh informan menunjukkan bahwa nasabah yang diberikan potongan angsuran murabahah hanyalah mereka yang melakukan pelunasan sebelum jatuh tempo sedangkan dua sebab lainnya tidak masuk dalam kebijakan tersebut. Kebijakan ini seakan menafikan kedua kondisi lainnya sehingga pada prakteknya hanya satu kondisi yang berikan peluang untuk di berikan potongan margin. Dengan demikian prestasi yang disebutkan oleh Wiroso (2011: 113) adalah karena telah membantu mempercepat realisasi keuntungan bagi perbankan syariah bukan karena terpenuhinya kewajiban nasabah dalam waktu yang telah di tentukan, apalagi karena penurunan kemampuan membayar.

Percepatan keuntungan yang diperoleh perbankan syariah sangat logis dilakukan karena semakin cepat perputaran uang dalam pembiayaan murabahah maka 
semakin baik untuk perkembangan perbankan syariah. Dengan kondisi ini, posisi perbankan syariah berada dalam "zona nyaman" sehingga tidak mengherankan jika ada salah satu perbankan syariah yang sengaja mencatumkan kondisi ini ke dalam akad murabahahnya. Dalam akad tersebut tertulis bahwa "Dalam hal nasabah melakukan pelunasan dipercepat, bank dimungkinkan dapat memberikan potongan dari kewajiban pembayaran". Walaupun bukan merupakan sebuah janji yang tersurat di dalam akad murabahah namun trik ini menjadi daya tarik memikat bagi calon nasabah pembiayaan.

Penafian terhadap kedua kondisi ini juga menunjukkan realitas sebaliknya yaitu tidak memberikan keuntungan kepada perbankan syariah. Pelunasan tepat waktu bersifat "normal" dan tidak berdampak secara signifikan terhadap perolehan keuntungan walaupun target yang direncanakan telah tercapai. Apalagi pemberian potongan margin karena penurunan kemampuan membayar angsuran, kondisi ini merupakan "penyimpangan" terhadap target keuntungan yang telah direncanakan sehingga menjadi mustahil jika kondisi dilakukan. Hal ini pun beralasan karena bank tidak mau menanggung kerugian atas wanprestasi nasabah. bank syariah tetap akan menetapkan kebijakan agar keuntungan tidak hilang atau berkurang dari hasil pembiayaan marabahah. Jika kebijakan pemberian potongan margin diterapkan karena ketidakmampuan nasabah maka bank akan mengalami kerugian. Kasarnya, nasabah sudah menyusahkan masih mau menyusahkan dengan mengurangi keuntungan dari pembiayaan murabahah.

Kemustahilan ini juga berdasar, sebagaimana dijelaskan sebelumnya bahwa penurunan kemampuan pembayaran atau keterlambatan pembayaran (PSAK 102 paragraf 29 dan Fatwa DSN-MUI No 17/DSN-MUI/IX/2000) walaupun dengan syarat jika lalai namun realitasnya tetap dikenai denda sehingga potongan tersebut tidak mungkin dberikan. Jika tidak mampu secara keseluruhan maka objek pembiayaan murabahah yang di jadikan jaminan akan dilelang untuk menutupi kekurangan pembayaran tersebut. Maka sangat jelaslah kondisi tidak akan mungkin terjadi dan sebaiknya ketentuan pemberian potongan sebagaimana tertuang dalam PSAK 102 paragraf 28 dan fatwa DSN-MUI dihapuskan saja. Kecuali, perbankan syariah lebih berfokus kepada pemerataan kesejahteraan rakyat (kemaslahatan ummah) sebagaimana amanat UU No 21 tahun 28.

Penerapan kebijakan ini menunjukkan karakter egoistik perbankan syariah yang berorientasi materialistik. Kebijakan ini bertujuan hanya kepada bagaimana keuntungan secepatnya diterima oleh perbankan syariah. Sedangkan kondisi yang lain terkhusus kebijakan potongan margin terhadap ketidakmampuan nasabah dalam penyelesaian pembayaran angsuran merupakan bagian penting bagi perbankan syariah untuk mengimplementasikan nilai-nilai Islam sebagai pondasi utama yang menjadi pembeda dengan perbankan syariah. Ajaran Islam menegaskan tentang prosedur hutang-piutang di mana diapabila orang yang diberi hutang memiliki keterlambatan dalam penyelesaian hutangnya karena kondisi tertentu maka 
diberikan keringanan dan apabila tidak mampu dianjurkan untuk dihapuskan. Penghapusan hutang dalam kaidah hutang-piutang jika dipahami secara mendalam maka memiliki kaitan dengan potongan atas ketidakmampuan membayar. Artinya, penghapusan di sini dapat diartikan sebagai potongan margin yang diberikan kepada nasabah dengan tujuan memberikan kemudahan kepadanya. Menurut Muhamad (2012: ix) seharusnya kebijakan yang di ambil harus serasi dengan etos islam dan mampu memenuhi aspirasi umat.

Menurut Widodo (2010:50), pemberian potongan atas pelunasan sebelum jatuh tempo menempatkan nasabah pada posisi yang sangat lemah. Bagaiaman tidak, ada kemungkinan nasabah juga tidak diberikan potongan karena semua tergantung dari kebijakan perbankan syariah. Nasabah tidak mampu bertindak apapu, misalnya protes atau menuntut secarah huku, perdata pidana ataupun syariat islam. Hal dikarenaka potongan tersebut bersifat tidak mengikat karena tidak diperjanjikan di awal kesepakatan. Kondisi ini juga menunjukkan sikap egoistik perbankan syariah.

Menelusuri pemberian potongan margin karena pelunasan dipercepat mengundang sebuah pertanyaan bagi peneliti yaitu "siapakan yang mendapatkan potongan margin? Jawabannya adalah tidak ada nasabah yang diistimewakan untuk mendapatkan potongan margin karena semua memiliki kesempatan yang sama dengan catatan harus mampu melakukan pelunasan lebih awal. Muncul kembali pertanyaan baru yaitu "siapakan yang mampu melakukan pelunasan lebih awal". Untuk menjawab pertanyanan ini diperlukan penelusuran mendalam dengan menggunakan logika sederhana.

Kesempatan melakukan pelunasan lebih awal untuk mendapatkan potongan margin terbuka untuk semua nasabah baik nasabah yang tergolong kelas bawah (masyarakat berpenghasilan rendah atau usaha mikro dan kecil) maupun kelas atas (masyarakat berpenghasilan menengah atau usaha menengah dan besar). Namun, tanpa menganggap remeh kemampuan nasabah kelas bawah, secara logis yang mampu melakukan pelunasan lebih awal biasanya adalah nasabah yang memiliki kemampuan finansialnya memadai dan yang lebih mampu adalah nasabah kelas atas (individu maupun dunia usaha). Realitas ini menimbulkan dominasi nasabah kalangaan atas untuk mendapatkan potongan margin karena mayoritas potongan margin hanya akan diberikan kepada mereka. Sebaliknya, kondisi ini kemudian akan membentuk alienasi dalam potongan margin dimana nasabah kelas bawah akan tereliminasi dan berujung pada diskriminasi.

Pemberian potongan margin yang didominasi oleh nasabah kelas atas tentunya akan memberikan kemudahan dalam pembayaran angsuran yang pada akhirnya dapat meningkatkan tingkat kesejahteraannya atau dengan kata lain upaya peningkatan kesejahteraan lebih mudah sedangkan nasabah kelas bawah akan berbanding terbalik dengan kondisi mereka dan pada akhirnya memunculkan ketimpangan kesejahteraan di masyarakat. Kondisi ini akan memunculnya ketimpangan kesejahteraan yang tentunya bertentangan dengan tujuan utama perbankan syariah. 


\section{SOLUSI}

\section{Atas Realitas Dalam Prespektif Nilai Kedermawanan Islam Tjokroaminoto}

Substansi nilai kedermawanan Islam sebagaimana dijelaskan oleh Tjokroaminoto (1950:29) mencakup 3 (tiga) bentuk yaitu mengedepankan keperluan orang lain yang membutuhkan, membagi kekayaan (baca: harta) secara adil dan merata, dan membahagiakan orang yang memerlukan (orang miskin). Ketiga bentuk ini pada hakekatnya mengarah kepada satu tujuan yaitu keberpihakan kepada orang (baca: nasabah) yang membutuhkan sehingga tercapai keadilan kesejahteraan secara menyeluruh.

Tjokroaminoto (1950:49) menyampaikan Firman Allah dalam QS Al-Baqarah ayat 280 , yang sejalan dengan realitas nilai kedermawanan Islam dalam margin murabahah yaitu:

“ Djanganlah berlaku tidak adil oleh lain-lain orang. Kalau ada seorang (berhutang) di dalam hal-ichwal yang susah, haruslah ia diberi tempo sampai ia datang pada hal-ichwal jang susah gampang tetapi kalau kamu memberikan (hutang) sebagai sedekah adalah lebih baik bagi kamu, kalau kamu telah mengetahui itu"

Esensi dari ayat ini adalah fokus utama dalam nilai kedermawanan Islam adalah orang-orang yang memang sangat membutuhkan pertolongan dalam proses penyelesaian pembayaran angsuran. Sehingga tahap awal adalah evaluasi subyek untuk alokasi potongan margin. Di sisi lain, ayat tersebut menyinggung tentang sedekah yang bertalian dengan potongan margin sehingga objek potongan margin diprioritaskan kepada nasabah yang tidak mampu melunasi pembayaran angsuran.

Penelusuran secara mendalam dari realitas di atas memberikan gambaran bahwa potongan margin akan lebih didominasi oleh nasabah kelas atas. Kemampuan finansial yang dimilikinya menguatkan status mereka sebagai nasabah yang berhak mendapatkan potongan margin. Nasabah kelas atas dalam penelitian ini diwakili oleh masyarakat berpenghasilan menengah dan atas atau usaha menengah dan besar.Realitas ini jika ditelusuri lebih mendalam dengan bingkai nilai kedermawanan Islam, akan terlihat bahwa terdapat kesalahan target atau sasaran dalam menggulirkan potongan margin.

Berlatar belakangkan kondisi ini, diperlukan perbaikan pada target subjek yang tepat dalam pengalokasian potongan margin di perbankan syariah. Hakikat kedermawanan adalah kepedulian kepada yang membutuhkan sehingga jika substansi nilai kedermawanan diaplikasikan dalam alokasi potongan margin maka kebijakan ini akan lebih diarahkan kepada nasabah yang memiliki tingkat kesejahteraan di bawah rata-rata. Artinya, dalam penelitian ini nasabah dimaksud adalah nasabah 
yang berpenghasilan rendah atau usaha mikro dan kecil. Dengan demikian, mengenal dan memastikan target merupakan langkah awal dalam restrukturisasi nilai kedermawanan Islam di perbankan syariah.

Wiroso (2010:113) menyatakan bahwa analisis kejujuran dan transparansi yang tinggi dari perbankan syariah diperlukan untuk memastikan bahwa nasabah tersebut memang memiliki ketidakmampuan dalam melunasi kewajibannya. Artinya, perbankan syariah memerlukan prosedur yang tepat dan meyakinkan untuk memastikan kebenaran kondisi nasabah tersebut. Analisis perbankan syariah perlu diawali dengan membedakan antara nasabah yang memiliki ketidakmampuan karena bawaan dari asalnya yaitu tingkat kesejahteraan memang dibawah rata-rata dengan nasabah yang tidak mampu mengangsur karena kondisi insidental. Kedua kondisi ini berbeda karena pada hakekatnya kondisi yang membutuhkan uluran tangan adalah mereka yang bawaannya memang "kurang" di mana berpengaruh terhadap kemampuan angsurannya sedangkan nasabah yang non-miskin kondisi ketidakmampuannya hanya bersifat sementara. Dengan demikian, nasabah yang ditargetkan sebagai penerima potongan margin adalah mereka yang secara substansi memiliki keterbatasan ekonomi bukan ketidakmampuan dadakan.

Solusi yang kedua berkaitan dengan objek potongan angsuran murabahah. Objek potongan margin menjelaskan tentang latarbelakang diberikannya kebijakan tersebut. Penjelasan sebelumnya menggambarkan bahwa potongan margin diberikan karena alasan pelunasan lebih awal atau sebelum jatuh tempo, sebagaimana diatur dalam PSAK PSAK 102 paragraf 26 dan 27 dan disahkan dengan Fatwa DSN Nomor 23/DSN-MUI/III/2002. Selain itu, PSAK 102 paragraf 28 dan Fatwa DSN Nomor 46/DSN-MUI/II/2005 juga mengatur potongan margin dengan syarat ketepatan waktu dan ketidakmampuan nasabah melakukan pembayaran angsuran. Dengan demikian, terdapat 3 (tiga) kondisi yang menimbulkan adanya pemberian potongan margin kepada nasabah yaitu pelunasan sebelum jatuh tempo, pelunasan tepat pada waktunya dan ketidakmampuan nasabah dalam melunasi.

Ketiga kondisi, ini jika di kaitkan dengan subjek yang menjadi target dalam implementasi nilai kedermawanan Islam maka kondisi yang lebih kuat akan mengarah kepada pemberian potongan margin bagi nasabah yang tidak mampu melunasi. Kepedulian terhadap nasabah ini merupakan unsur penting dalam substansi pokok pilar kedermawanan Islam. Hal ini didasarkan pernyataan dalam QS Al-Baqarah ayat 280 yang berbunyi:

"Dan jika (orang yang berhutang itu) dalam kesukaran, Maka berilah tangguh sampai dia berkelapangan. dan menyedekahkan (sebagian atau semua utang) itu lebih baik bagimu, jika kamu mengetahui." 
Dan Hadits Nabi Sallahualihi wasallam dalam Shahih Ibnu Majah No. 1963

"Barangsiapa yang ingin dinaungi Allah dengan naungan-Nya (pada hari kiamat,), maka hendaklah ia menangguhkan waktu pelunasan hutang bagi orang yang sedang kesulitan, atau hendaklah ia menggugurkan hutangnya."

Kedua kalimat Ilahiyah diatas menegaskan bahwa nasabah yang memiliki kesulitan dalam memenuhi kewajibannya menjadi prioritas untuk diberikan kemudahan. Kemudahan dapat berupa penangguhan pembayaran dimana diberikan kelonggaran waktu sampai nasabah tersebut dapat melunasinya. Namun, jika kelonggaran waktu yang diberikan telah lewat dan kondisinya tetap sama maka angsuran (baca: margin) pada bulan tersebut dihapus atau digugurkan. Menurut Muhamad (2012: 173), perbankan syariah yang didukung oleh DSN-MUI tahu dan paham tentang susbtansi firman ini akantetapi mereka mempersempit makna perintah ini. Keterangan diatas juga menunjukan bahwa besaran margin dapat dihapus seluruhnya dalam bulan tunggakan namun bisa juga sebagian. Kondisi ini menunjukan adanya pilihan bagi perbankan syariah untuk menentukan besaran potongan margin atau berdasarkan kebijakannya. Inilah hakikat implementasi kedermawanan Islam dalam margin murabahah di perbankan syariah.

Upaya solutif yang ketiga perkaitan dengan besaran potongan margin murababah. Paparan sebelumnya menjelaskan bahwa besaran potongan margin ditentukan sepenuhnya oleh perbankan syariah. Realitas menunjukan bahwa terkadang besaran potongan margin yang diberikan 1 kali atau 2 kali margin akan tetapi ada pula yang masih perlu dinegosiasikan dengan atasannya. Namun menurut peneliti, penentuan besarnya potongan margin lebih efektif menggunakan negosiasi dengan atasan melalui berbagai pertimbangan untuk mendapatkan porsi besaran yang sesuai.

Hakikat diberikannya potongan margin bertujuan untuk meringankan kesulitan nasabah kelas bawah dalam pembayaran angsuran murabahah. Bergerak dari tujuan tersebut, seharusnya besaran potongan margin didasarkan kepada kondisi nasabah. Artinya, semakin kecil peluang nasabah kelas bawah untuk menyelesaikan kewajibannya maka semakin besar potongan margin yang diberikan. Demikian pula sebaliknya, semakin besar kemungkinan nasabah kelas bawah menyelesaikan kewajibannya maka semakin kecil potongan margin diberikan. Dalam kondisi seperti ini keberadaan negosiasi dengan atas sangat diperlukan karena dibutuhkan analisis tingkat kesejahteraan dengan berbagai indikator untuk memastikan kondisi nasabah. Jika nasabah dalam kondisi yang tidak memungkinkan pelunasan.

Berdasarkan penjelasan dalam QS. Al-Baqarah 280 disebutkan bahwa sebagai bentuk sedekah kepada terhutang maka besaran yang dinginkan adalah sebagian atau seluruhnya. Dalam konteks margin, ini menunjukan bahwa perbankan syariah 
dapat menentukan potongan margin sebesar sebagian atau seluruhnya dari sisa angsuran marginnya. Kembali lagi bahwa potongan margin yang dari sebagian atau seluruh dari sisanya ditetapkan berdasarkan kondisi nasabah. Walhasil, besaran potongan margin yang efektif adalah dikondisikan berdasarkan kondisi nasabah. Jika hasil analisis perbankan syariah menunjukan bahwa nasabah kelas bawah tidak memiliki kemampuan untuk menyelesaikan kewajibannya maka potongan margin semakin besar dan sebaliknya. Tujuan yang ingin dicapai adalah meringankan kesulitan nasabah kelas bawah sebagai perwujudan dari nilai kedermawanan Islam di perbankan syariah.

\section{SIMPULAN}

Realitas menunjukkan bahwa dominasi keuntungan masih mendominasi dalam kebijakan pemberian potongan margin atas pelunasan pembayaran angsuran murabahah. Keuntungan menjadi dasar pijakan kebijakan yang mencirikan sikap materialistik yang memunculkan perilaku egoistik sehingga kebijakan pemberian potongan margin hanya diberikan kepada nasabah yang melakukan pelunasan lebih cepat. Solusi atas realitas ini adalah dengan menggunakan nilai kedermawanan islam Tjokroaminoto dengan mengevaluasi tiga yaitu yang pertama adalah subyek penerima potongan yaitu diutamakan kepada nasabah yang benar-benar membutuhkan pertolongan sehingga memudahkannya menyelesaikan angsuran murabahahnya. Yang kedua, obyek potongan margin dimana diutamakan kepada kondisi karena penurunan kemampuan membayar angsuran murabahah. Yang ketiga adalah besaran porsi potongan di mana tergantung kepada kondisi nasabah dan kepentingan perbankan syariah. Solusi ini menunjukkan adanya upaya internalisasi nilai secara menyeluruh termasuk dalam kebijaka pemberian potongan margin sehingga menjadi corek pembeda dengan perbankan konvensional. Upaya pemecahan masalah ini digunakan untuk mencapai cita-cita perbankan syariah sesuai dengan amanat UU No 21 tahun 2008.

\section{DAFTAR PUSTAKA}

Departemen Agama Republik Indonesia. 2005. Al-Quran Terjemahan. Jakarta: PT. Syamil Cipta Media.

Djamhuri, A. 2011. Ilmu Pengetahuan Sosial dan Berbagai Paradigma dalam Kajian Akuntansi. Jurnal Akuntansi Multiparadigma vol 2, No 1. Malang.

DSN-MUI. 2005. Fatwa Dewan Syari'ah Nasional No. 46/DSN-MUI/II/2005 tentang Potongan Tagihan Murabahah (khashm fi al-murabahah). Jakarta.

Ikatan Akuntan Indonesia. 2007. Pernyataan standar akuntansi keuangan 102, Akuntansi murabahah. Dewan Standar Akuntansi Keuangan Ikatan Akuntan Indonesia. Jakarta.

Muhamad. 2012. Teknik Perhitungan Bagi Hasil dan Pricing di Bank Syari'ah. Yogyakarta: UII Press.

El-Muhasaba, Vol. 7, No 1, Januari 2016 
Mulawarman, A.D. 2014. Akuntansi “Tjokro-an" Kritis ala Hos Tjokroaminoto. Makalah dipresentasikan pada Accounting Research Training Series 5. Program Doktor Ilmu Akuntansi. Fakultas Ekonomi dan Bisnis Universitas Brawijaya. Malang.

Prastowo, A. 2012. Metode Penelitian Kualitatif Dalam Perspektif Rancangan Penelitian. Jogjakarta: Ar Ruzz Media.

Rivai, V., dan Usman, A.N. 2012. Islamic Economic and Finance. PT. Gramedia Pustaka Utama. Jakarta. Soetriono dan Rita, H. 2007. Filsafat Ilmu dan Metodologi Penelitian. Yogyakarta: Andi.

Suka, G. 2012. Dominasi Dalam Perspektif Teori Kritis. Jurnal Pustaka Volume XII, No. 1, Februari 2012.

Tjokroaminoto.1950. Islam dan socialisme. Jakarta.

Triyuwono, I. 2011. Angels: Sistem Penilaian tingkat kesehatan bank Syari'ah. Jurnal Akuntansi Multiparadigma Jurusan Akuntansi Fakultas Ekonomi dan Bisnis Universitas Brawijaya. Volume 2, Nomor 1, April 2011. Malang.

Undang-Undang Republik Indonesia. 2008. Perbankan Syariah. Jakarta

Widodo, S. 2010. Seluk Beluk Jual Beli Murabahah, Prespektif Aplikatif. Yogyakarta: Asgard Chapter.

Wiroso. 2010. Akuntansi Transaksi Syariah. Jakarta: Ikatan Akuntan Indonesia.

Yasin, W. 2010. Penerapan Prinsip Syariah Dalam Pelaksanaan Akad Murabahah. Jurnal Ilmu Hukum.vol.10, No. 1, Maret 55-56. 